\title{
SCALE DEFORMITIES IN NILE TILAPIA, OREOCHROMIS NILOTICUS, (ACTINOPTERYGII: CICHLIDAE) FROM SUDAN
}

\author{
Laith A. JAWAD
}

15 Birkinshaw Grove, Riverstone Terraces, Upper Hutt, Wellington, New Zealand

Jawad L.A., 2005. Scale deformities in Nile tilapia, Oreochromis niloticus, (Actinopterygii: Cichlidae) from Sudan. Acta Ichthyol. Piscat. 35 (1): 61-63.

\begin{abstract}
Scale deformity in Nile tilapia, Oreochromis niloticus, (Actinopterygii: Cichlidae) is reported for the first time from Dongola, north of Sudan. The abnormal scales are fused pairs, with two well-developed foci. Developmental irregularity, probably caused by partially arrested growth, is believed to be the cause of such deformity.
\end{abstract}

Key words: fish, scale abnormality, Nile tilapia, Oreochromis niloticus, adverse environment, Sudan

Reporting specific types of anomalies in fishes is important when defining whether these incidences can be related to habitat degradation. Abnormalities in scale morphology have rarely been reported: Taki (1938) described them in the wavyband sole, Zebrias japonica; Gunter (1941, 1945, 1948) found them in red drum, Sciaenops ocellatus, and other fish species; and Mookerjee (1948) recorded them in coitor croaker "Sciaena coitor" (= Johnius coitor). Recently, Corrales et al. (2000) reported on scale disorientation. The case of abnormal, Siamese scales (see below for the description of the condition) in Nile tilapia, Oreochromis niloticus (L.), dealt with here, is only the second record of multiple foci (the first was provided by Mookerjee 1948).

Thirty specimens of $O$. niloticus $(300-320 \mathrm{~mm}$ standard length) were obtained in August 1994 from Dongola (north of Khartoum City, Sudan). Ten of them had deformed ("Siamese-like") scales on the caudal peduncle area. All the Siamese scales were originals and not replacement scales; this conclusion was based not only on the size of the scales, but also on the size of the foci relative to the normal scales in the same body region of the same fish. Adjacent scales and those from other regions of the body were also carefully examined for comparison; all appeared to be normal.

The abnormal scales (Fig. 1A) were fused pairs, with two well-developed foci instead of one. The appearance of those scales was completely different from that of a normal scale (Fig. 1B). Both foci lie in the central zone of the scale, with the left focus situated a short distance below the right, larger, focus. The focus of the left (ventral) scale is circular, while that of the right (dorsal) scale is elongated. Both foci are bounded by a complete concentric circuli. The circuli around the focus of the dorsal scale are also longitudinal in shape. The circuli anterior to the focus of the left scale are irregular and encircle two small areas. The abnormal scales showed 13-15 complete radii, 4-6 incomplete radii on the left scale, and 13-16 complete and 6-8 incomplete radii on the right scale. Some of the radii from both left and right scales were not straight. All the abnormal scales had the anterior part of the posterior field of the right scale fused to the dorsal part of the posterior field of the left scale. The lines of granulation in the posterior field of the left scale abnormally encircle the focus. The posterior end of the left scale was elongated rather than rounded, with a deformed lower edge. The left scale had a more inclined anterior edge.

The single abnormal bifocal scale reported from Johnius coitor by Mookerjee (1948) differed in shape from those described here: they were elongateoval with an entire margin. With respect to the scales described in this note, it might be imagined that-late in the development and owing to some developmental irregularity probably caused by arrested growth - the two scales were fused to form a common layer. The hyalodentine of each scale was already calcified prior to fusion, and retained its own foci in spite of fusion of the layers. Thereafter and despite the fusion, development of the ornamentations of the two scales proceeded in a normal way, although the left scale was abnormal.

Four main categories of agents are considered to be responsible for scale abnormality in fishes: genetic disorders, diseases, physical, and chemical environmental variables (Corrales et al. 2000). Apart from the work of Mahgoub and Dirar (1986) and Musa et al. (1999) on microbial contamination, there has been few publications on water quality in northern Sudan. Bacterial infections and infections by protozoan and non-protozoan parasites were reported for O. niloticus in Egypt (El-Khatib 1998, Abo El-Alla

\footnotetext{
${ }^{*}$ Correspondence: Dr. Laith A. Jawad, Museum of New Zealand, Te Papa, 169 Tory St., Wellington, New Zealand, e-mail: Laith@tepapa.govt.nz
} 


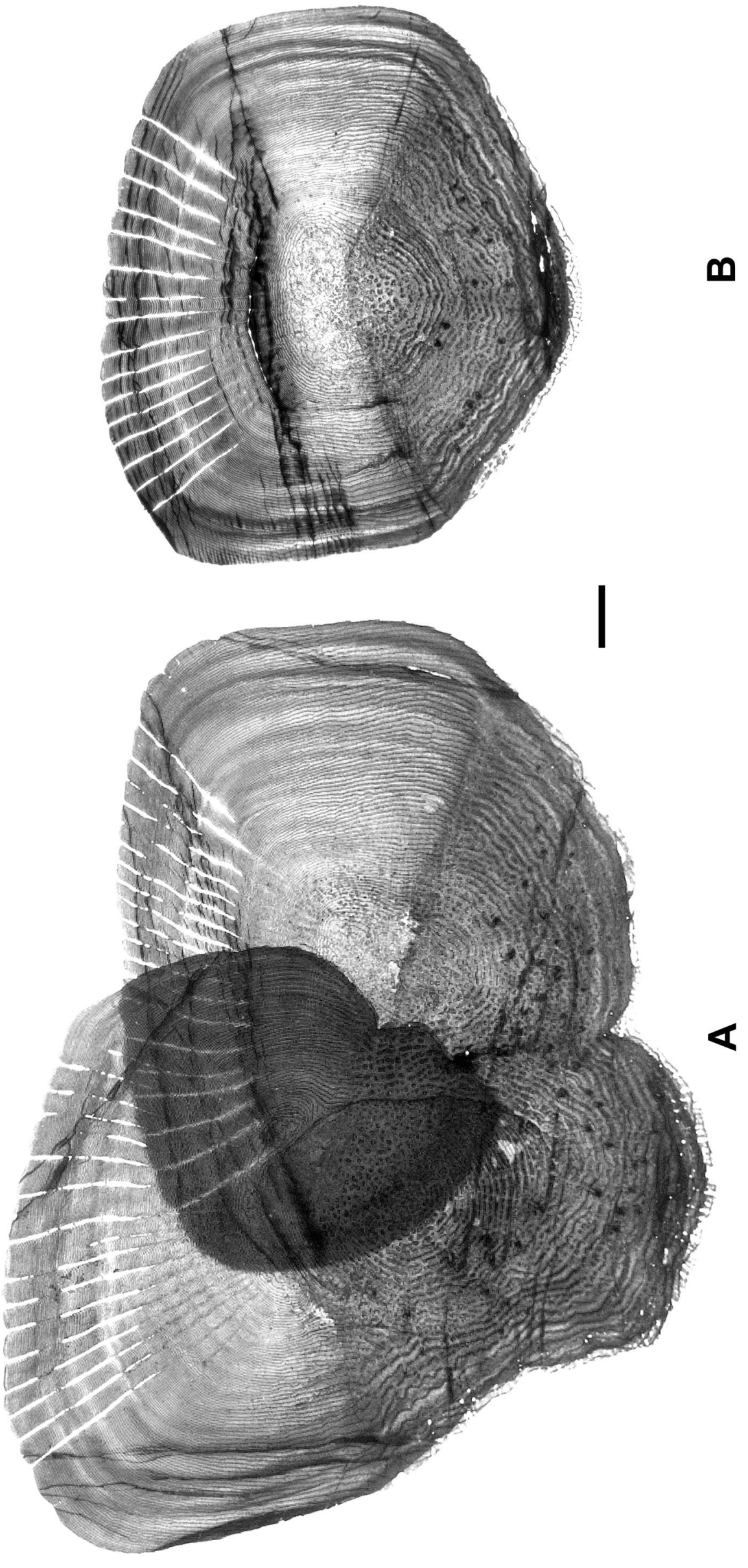


and Bastawrows 1999, Bastawrows and Mohammed 1999, Hagras et al. 2000, El-Mansy and Abdel-Gaffar 2003). There have been several studies on the Nile tilapia in the southern part of Egypt, a few hundred kilometres from the source of specimens for the present study (Awadallah et al. 1996, Dekov et al. 1997, Adham et al. 2001).

Lack of information on the Nile tilapia in Sudan prevents suggesting a definitive cause of the abnormality described in this work. Further study is clearly needed; it should focus on the question (1) whether the removal of abnormal scales will lead to replacement by normal or abnormal scales, and (2) whether such abnormalities can be experimentally induced or observed in aquaculture, since the species is frequently cultured. Research along those lines, including also the frequency of occurrence of abnormal scales, should provide insights into the causeeffect relationships by revealing potential correlations with environmental variables or genetic traits.

\section{ACKNOWLEDGEMENTS}

I would like to thank Bruce Marshall and Raymond Coory, both of the Museum of New Zealand Te Papa Tongarewa, for their continued advice and suggestions in preparing the manuscript and for technical assistance in preparing the figure. I would also like to thank Michael C. Schmale, Division of Marine Biology and Fisheries, University of Miami for his valuable comments.

\section{REFERENCES}

Abo El-Alla A.A., Bastawrows A.F., 1999. Occurrence and significance of some aerobic pathogens in Oreochromis niloticus and Labeo niloticus fishes in Assiut. Assiut Veterinary Medical Journal 42 (2): 174-190.

Adham K.G., Hamed S.S., Ibrahim H.M., Saleh R.A., 2001. Impaired functions in Nile tilapia, Oreochromis niloticus (Linnaeus, 1757), from polluted waters. Acta Hydrochimica et Hydrobiologica 29 (5): 278-288.

Awadallah R.M., Soltan M.E., Rashed M.N., 1996. Relationship between heavy metals in mud sediments and beach soil of the River Nile. Environment International 22 (2): 253-258.

Bastawrows A.F., Mohammed A.A., 1999. Some microbiological investigations on Aeromonas hydrophila group in Oreochromis niloticus and Clarias lazera in Assiut Governorate. Assiut Veterinary Medical Journal 40 (2): 197-209.
Corrales J., Nye L.B., Baribeau S., Gassman N.J., Schmale M.C., 2000. Characterization of scale abnormalities in pinfish, Lagodon rhomboides, from Biscayne Bay, Florida. Environmental Biology of Fish 57 (2): 205-220.

Dekov V.M., Komy Z., Arauji F., Van Put A., Van Grieken R., 1997. Chemical composition of sediments, suspended matter, river water and ground water of the Nile (Aswan-Sohag traverse). Science of Total Environment 201 (3): 195-210.

El-Khatib N.R.H., 1998. Some studies on eye infection in Oreochromis niloticus in Egypt. Veterinary Medical Journal, Giza 46 (1): 43-55.

El-Mansy A.E., Mazen A.M.A., 1996. Isolation of Cd-binding protein of water hyacinth (Eichhornia crassipes) grown in Nile River water. Water, Air and Soil Pollution 87: 357-362.

Gunter G., 1941. A rare abnormality, a fish with reversed scales. Copeia 1941 (3): 176.

Gunter G., 1945. Another redfish, Sciaenops ocellatus (Linnaeus) with reversed scales. Ichthyological Notes 1945 (1): 55.

Gunter G., 1948. A discussion of abnormal scale patterns in fishes, with notice of another specimen with reversed scales. Copeia 1948 (4): 280-285.

Hagras A.E., El-Naggar M.M., Ogawa K., Hussein A.B., ElNaggar A.M., 2000. Effect of some ecological parameters of the monogenean gill parasites on the cichlid fish Oreochromis niloticus and Tilapia zilli from Manzala Lake and Mansoria Canal at east northern delta, Egypt. Journal of Egyptian-German Society of Zoology D 32: 205-221.

Mahgoub D.M., Dirar H.A., 1986. Microbial pollution of the blue and white Niles at Khartoum. Environmental International 12 (6): 603-609.

Mookerjee S., 1948. An atypical scale of Sciaena coitor (Hamilton). Nature 161 (4080): 64-65.

Musa H.A., Shears P., Kafi S., Elsabag S.K., 1999. Water quality and public health in northern Sudan: a study of rural and peri-urban communities. Journal of Applied Microbiology 87 (5): 676-682.

Taki I., 1938. On the abnormal arrangement of scales and colour bands in a sole Zebrias, with special reference to its adverse scales. Journal of Science Hiroshima University B 6 (3): 1-14

Received: 23 March 2005 Accepted: 2 June 2005 